\title{
The Thirty-First Annual Conference of the Association of Muslim Social Scientists
}

The Association of Muslim Social Scientists (AMSS) held its thirtyfirst annual conference in Washington, DC, from October 25-27, 2002, with the collaboration of the International Institute of Islamic Thought (IIIT). The conference was cosponsored by the School of International Service, American University, and supported by the university's Ibn Khaldun Chair of Islamic Studies, Dr. Akbar Ahmed.

In his welcoming remarks, Dr. Louis Goodman, Dean of the School of International Service, American University, encouraged the use of academic forums to highlight social concerns of the larger world community. 
Introductory comments by AMSS President Dr. Louay Safi, stressed the need for scholars to examine the different agendas being introduced to address concepts dealing with the fears and concerns faced by the larger Muslim and non-Muslim communities in a post-9/11 world. The Conference Chair, Dr. Amira Sonbol, Georgetown University, DC, hoped that this conference would promote debate on how Islam has been studied to date, and encourage Muslims to revisit moments in history to understand their community's position in world history.

The conference theme, "The Muslim World after September 11: Agenda for Change," echoed in the presentations made by over 40 scholars in eight consecutive panels, one roundtable discussion, a plenary session, and a keynote address at the annual banquet. Students, academicians, activists, and intellectuals engaged in a lively debate with the panelists after their presentations. Media coverage was provided by the Washington Post and the Washington Times.

The subthemes of the three panels held on the first day, starting with the plenary session, were "Muslims in America: Constitution and Civil Rights," "American Muslims and American Politics," and "Fighting Terrorism." These panels introduced the concept that after 9/11, the Muslim community's future position in both American and world history will be determined by its engagement in the larger world debate on social concerns. It was, however, in the plenary session that Dr. Muqtedar Khan (Adrian College, MI), Dr. Nazif M. Shahrani (Indiana University, IN), Dr. Peter Gran (Temple University, PA), and Dr. Ahmad Dallal (Stanford University, CA) identified the reasons why a new communication agenda is warranted in the larger Muslim community. Keeping history in perspective was identified as a key concept for understanding how the socioeconomic and political developments in the Muslim world during the modern era led to its current position in world history.

Khan, while examining the need for change, explained in his "American Muslims and the Crisis of Civil Rights," why "one of the most important casualties of the war on terror is the deteriorating condition of civil rights protection for Muslims in America." Since protecting Muslim civil rights requires involvement in the political process, it is important to understand how and why such involvement affects a community's stature in both local politics and world history. This point was reinforced by Dallal's "The Right to Remain Connected: Links between the Home Front and the Muslim World," in which he argued that the American Muslim community's impact and influence on events in world history is based on its involvement in local politics, because foreign policy is part of local politics. He explained that the 
"globe is being shaped today ... with the foreign policy strategy of this administration. If we bury our heads in the sand and do not deal with anything except [issues affecting] our local communities in the US, those [neglected global] issues will come back to haunt us."

In his "War on Terrorism: A Solution to or a Problem for U.S. National Security," Shahrani added that keeping history in perspective is absolutely critical for Muslims "if they are going to understand why they are stuck with the agenda that was done for [them] by others ... Understanding why events happened in particular moments in history" is thus the key to defining the Muslim community's current position in history. For example, he argued that the industrial revolution, not Islam, "tipped the balance for Europeans against the Muslim world."

Gran's "Muslims in America: The Role of Historiographical Debates on the Formation of Civil Identity by Extension of Civil Rights under Laws" provided valuable insight on how American Muslims should proceed in reclaiming their identity. He focused on their need to "know where the Muslim community fits in American and world history. It is against this larger background that what is possible and what is not possible" can be understood when defining an agenda for change.

In the second panel, "Roundtable: American Muslims and American Politics," Safi's statement reinforced Dallal's viewpoint that Muslim American involvement in local politics is crucial if Muslims are going to have a voice in the larger world debate and influence foreign policy. In his "New Roles for Muslim Scholars: Post September 11," Safi argued that "Islam as the motif for moral and social behavior is central to the reform efforts. Also central is a free debate and open dialogue in which ideas are discussed freely in the public square ... [and herein] lies the important role of Muslim scholars and Islamic scholarship."

The third panel, "Fighting Terrorism," included analyses by Waleed elAnsary (George Washington University, DC) and Omar Altalib (Ashland University, $\mathrm{OH}$ ) that highlighted the psychological worldview of terrorists. For example, in his "The Economics of Terrorism: How Bin Laden is Changing the Rules of the Game," El-Ansary defined three questions that policy makers must answer in order to apply game theory: "What are the 'rules' of the current terrorist game? What motivates terrorists in selecting one action over another? How does what terrorists think that we will do, affect their own selection?" On the other hand, Altalib examined the psychology of terrorism in his "Timothy McVeigh Versus Ramsi Yusuf: A Comparison," by explaining how the Oklahoma City bombing and the 
1993 New York City bombing [World Trade Center] "were political acts intended to get wide scale media attention and generate public shock."

The subthemes of the four panels held on the second day were "Islamic Visions for the Next Millennium," "Law and Gender," "Islamic Democracy and Clash of Civilizations," and "Muslims and the Media." These panels clearly drew attention to why developing communication and media skills to communicate effectively the difference between mainstream and extremist Islam is needed. In the panel "Islamic Visions for the Next Millennium," the Muslim community's engagement in the larger world debate on environmental concerns, genetic engineering, and challenges to traditional Islam's reform efforts was identified as crucial for the moral survival of its community and that of the larger world society.

For example, Dr. Mohamed Mestiri, director, AMSS-France, examined the need to contain radical movements in Islam that call for "uniformism" through political and religious means. In his "Radical Alternative and Uniformism: New Challenge for Islamic Reformism," Mestiri analyzed how such integral elements of Islam as diversity and tolerance are being challenged by violent methods of new forms of radical uniformism. He explained how "the religious aspect of this uniformism is based on an absolute assimilation of violence, intolerance and fanaticism to the Islamic ethics ..."

In "The Need for Methodology in Approaching Islamic Mystical Concepts," Seyyed Mesbahi (University of California-Berkeley) explained how Islamic concepts on mysticism are a major channel through which society can assess the relationship between the environment and mysticism. Discussing genetic engineering, another area of current social concern, Saeed A. Khan (Institute of Social Policy and Understanding, MI) argued in his presentation "Socioeconomic and Spiritual Consideration for the Human Genome Project" that Islamic perspectives on cloning, stem cell research, and genetic engineering must be pursued and become part of the international debate for the betterment of civilization. These presentations added a dimension to why the Muslim voice needs to be heard in the international dialogue on world issues.

In fact, presentations made during the second day show that if the mainstream Muslim voice is going to be heard, the larger Muslim community must change how it articulates its position on domestic and global issues. How to outline an agenda was best defined in "Muslims and the Media," a panel that examined how American Muslims need to proceed with their agenda in order to define their community's influence on American foreign policy and its future position in world history. In his "The Portrayal of the 
Islamic Community in the US," Daniel Micallef (University of Texas) analyzed how American Muslims can portray Islam's image to the U.S. media and the Bush administration. He stated: "Muslims cannot expect the U.S. administration to recognize the diverse elements of Islam if Muslims do not strive to articulate them." In his "Crisis Communication Strategies for the Media," Faizan Haq (State University of New York) addressed the handling of crisis communication as a basic survival skill needed by all organizations to communicate with the media successfully and confidently.

The annual banquet had two highlights. The first was Dr. John Esposito's (director, Center for Muslim-Christian Understanding, Georgetown University) keynote speech on how Muslims must address challenges facing their community and what AMSS needs to do to get its message across. He stated: "In today's America, people are searching the web all the time to see what Muslims have to say ... [therefore since] your program has a lot of important talks ... you should put them on the web." His argument that "AMSS needs to get out there on the lecture circuit more and be more visible in the media" confirms the key points outlined by the "Muslims and the Media" panelists. The second was the preview of "Muhammad: Legacy of a Prophet," produced by Alex Kronemer and Michael Wolfe, and shown by Lubna Ismail (president, Connecting Cultures, Inc). This film, to be aired on PBS on December 18th, will open another channel through which Muslims can provide the media with information on Islam.

The subthemes of the three panels held on the third day were "Political Economy, Globalization, and Economic Justice," "History and Culture: New Directions," and "Education and Future Generations." These panels provided new insight into how to use the forces of globalization, economic justice, literature, culture, religion and information technology as channels through which Muslims can examine their strengths and shortcomings and develop a new agenda that outlines their influence on foreign policy and defines their position in American and world history.

In the session on "History and Culture: New Directions," novelist Samia Serageldin (Duke University, NC) called upon the Muslim community in America to "examine the image [their image] in the popular imagination as reflected, and refracted through literature." In her "Reflections and Refractions: Arab American Women Writing and Written," Serageldin discussed the need to communicate the realities of Arab life to the larger American public through popular media like the novel. She also explained the "refracted" way by which Arabs and Muslims have been misunderstood in the western world. 
On the same panel, Kemal Ataman (Catholic University of America, DC) used his "New Insights in Tradition: The Relevance of al-Biruni" to call on Muslim intellectuals to reexamine the Islamic intellectual heritage, put such thinkers within their own age and historical context, and formulate new methodologies through which Islam and Islamic culture could be examined. The results of our understanding of Islam and the way it has come to be understood would be different from the normative view.

Dr. Imad ad-Dean Ahmad (Minaret of Freedom Institute, MD) presented his own new methodology in his "Disentangling Culture from Religion." In his presentation, he differentiated between Shari'ah and culture in an effort to distinguish Islam as a religion from what has become a cumulative body of knowledge formed of cultural traditions that is confused with Islam. Dr. Amira Sonbol, conference chair, followed the same theme by raising questions in her "Toward an Alternative History of the Islamic World" about how the history of the Muslim world and Islam has been studied so far. Her call for an alternative history pointed to the need for Muslims to become directly involved in writing their own history and to base that history not on polemics or by privileging religious writing alone. Rather, they should research particularly the Islamic world's rich archival records, for they present the concrete experience of the contemporary world's different Islamic societies. By referring to a famous Arab saying, "Those who forget their history are lost" (man fat qadimahu tah), Sonbol concluded that "to be able to move forward, Muslims have to first discover their past." 